\title{
ХУЙТЭН ДАЙНЫ ДАРААХИ МОНГОЛ УЛСЫН \\ ГАДААД ХАРИЛЦААНЫ БОДЛОГО БА \\ “ОЛОН ТУЛГУУРТ” ГАДААД ХАРИЛЦААНЫ БОДЛОГО
}

Х.САЙХАНСАНАА*

Д. ДАШ

\section{Оршил}

Зөвлөлт Холбоот Улс задарч, Зүүн Европын нөхцөл байдал өөрчлөгдсөнөөр Монгол Улсын гадаад харилцааны орчинд бодит өөрчлөлт гарч эхэлсэн. Үүнээс үҮдээд гадаад болон дотоодын улс төрийн шинэ нөхцөлд зохицохын тулд Монгол Улс хагас зууны турш баримталж ирсэн социалист үзэл баримтлалдаа маш том хувьсал хийсэн. Улс төрд ардчиллын үйл явц өрнөж, эдийн засгийн хувьд зах зээлийн эдийн засгийн тогтолцоо руу шилжин орсноор гадаад харилцааны хувьд Зөвлөлт Холбоот Улс руу чиглэсэн “нэг тал”-ыг баримталсан гадаад бодлогыг бүрэн орхиж, “олон тулгуурт гадаад харилцааны бодлого”-ыг баримтлах болов. Энэхүү бодлого нь дэлхийн томоохон гүрнүүдэд ихээр сайшаагдаж, ялангуяа АНУ Монгол Улсыг Зүүн хойд Азийн хамгийн хүчирхэг цэг хэмээн харах болсон. Иймээс өнөөгийн улс төрийн орчинд Монгол Улсын хэрэгжүүлж буй “олон тулгуурт гадаад харилцаа" нь бодит бөгөөд стратегийн ач холбогдолтой бодлого хэмээн олон улсын судлаачид үзэж байна.

\section{Нэг. Хүйтэн дайны дараах Монгол Улсын “Гадаад харилцааны олон тулгуурт бодлого"-ын ерөнхий тойм}

Монгол Улс нь хүйтэн дайны үед ЗХУ-тай бүх талаар хамтрах бодлогыг хэрэгжүүлж байсны үр дүнд Зүүн хойд Азийн бусад улс орнуудтай улс төр, эдийн засаг болон аюулгүй байдлын хүрээнд ямар ч харилцаагүй хаагдмал болгоход хүргэсэн бөгөөд энэ нь Монгол Улсад ихээхэн хохирол авчирсан. Энэхүү байдалд өөрчлөлт хийхийн тулд 1994 онд Монгол Улс “Монгол Улсын үндэсний аюулгүй байдлын үзэл баримтлал”, “Монгол Улсын гадаад бодлогын үзэл баримтлал”-ыг тус тус батлан гаргасан бөгөөд гадаад харилцааны үндсэн чиглэлээ “нээлттэй, эвсэлд үл нэгдэх, эрх тэгш харилцаа, олон тулгуурт бодлого” гэж тодорхойлсон юм. Эдгээр бодлогын гол зорилго нь Монгол Улсын тусгаар тогтнол болон үндэсний аюулгүй байдлыг хамгаалах явдал бөгөөд Орос, Хятад хоёр гүрэнтэй хөршийн найрсаг харилцааг баримтлан, Ази, Номхон далайн 
орнуудад байр сууриа батлан,“эвсэлд үл нэгдэн”, дэлхийн улс орнуудтай “эрх тэгш харилцаатай” байх, “олон тулгуур”-т тэнцүү бодлогыг баримтлахад чиглэсэн болно.

\section{1“Эвсэлд үл нэгдэх" гадаад харилцааны бодлого}

Монгол Улсын хэрэгжүүлж буй “эвсэлд үл нэгдэх” гадаад харилцааны бодлого нь дараах гурван агуулгаас бүрдэнэ. Үүнд:

Нэгд: Өөрийн улсын эрх ашиг хөндөгдөөгүй үед бусад улс орон Монгол Улсыг ашиглан бусад улсад аюул учруулахгүй байх,

Хоёрт: Монгол Улсын болон Төв Азийн орнуудын нутаг дэвсгэрт цөмийн болон бусад зэвсгийг байрлуулахгүй байх,

Гуравт: Өөрийн улсын үндэсний ашиг сонирхлыг хэрэгжүүлэхийн тулд Орос, Хятад 2 хөрш орныхоо маргаанд хөндлөнгөөс үл оролцон ямагт дундыг барих зэргээс бүрдэнэ. Монгол Улс нь энэхүү бодлогыг хэрэгжүүлснээр хүйтэн дайны үеийн дан ганц Зөвлөлт Холбоот Улс руу чиглэсэн өвөрмөц “нэг талын” хамтын харилцааны гадаад бодлогыг эцэс болгож улмаар Ази, Номхон далайн орнуудтай харилцаагаа маш хурдацтай хөгжүүлж эхэлсэн юм.

\section{2“Тэнцвэртэй харилцах" гадаад харилцааны бодлого}

Монгол Улс гадаад харилцааны бодлогоо батлах явцад хоёр хөрштэйгөө бүхэлдээ тэнцвэртэй харьцах харилцааг нэн тэргүүнд чухалчилж үзсэн юм. “Тэнцвэртэй харилцах" бодлого гэдэг нь Орос, Хятад 2 улстай улс төрийн адил тэнцүҮ бодлого баримтлах явдал биш бөгөөд харин тэдэнтэй харьцах эрх ашгийн харилцаанд дундын тэнцвэртэй байдлыг барих явдал юм. Монгол Улс нь Орос, Хятад улсын аль нэгтэй нь эвсэн нэгдэхгүй ба дайсагнахгүй, 2 улсын маргаанд оролцохгүй, “харилцан итгэлцлээ баталгаажуулан, хамтран ашигтай ажиллаж, бүх талаар хөгжих” бодлогыг явуулж байна.

\section{3“Олон тулгуурыг тэнцвэржүүлэх” гадаад харилцааны бодлого}

1995 онд “Тусгаар тогтнол” сонинд Монгол Улс гадны аюулд өртөх 8 магадлалын тухай бичсэн нийтлэл хэвлэгдэн гарсан бөгөөд тэрхүҮ магадлалын ихэнх нь Орос, Хятад улстай хамааралтай байсан юм. Иймээс “гуравдагч хөрш орон”-ы бодлого хэрэгжүүлж эхэлсэн байна. Монгол Улс нь гуравдагч хөрш орнуудтай харилцаагаа бататгаснаар 2 хөрш улсынхаа дунд тэнцвэртэй байх цэгийг олж ингэснээрээ улс орныхоо тусгаар тогтнол, аюулгүй байдлыг баттайгаар хамгаалж чадах юм. Хэрвээ улс орныг хэсэг эсвэл бүхэлд нь хамарсан дотоодын зөрчилдөөн үүссэн үед түүнчлэн гадны сүрдүүлэлтэд өртсөн үед Монгол Улсын тусгаар тогтнол, нийгмийн тогтолцоог хүлээн зөвшөөрч буй 
бусад улс орон ба олон улсын байгууллагаас тусламж хүсэх болно хэмээн Монгол Улсаас мэдэгдэж байсан болно.

Хоёр. Хүйтэн дайны дараах Монгол Улсын “олон талт" гадаад бодлогын үйл явц.

\section{1 “Нөхөрсөг хөрш” гадаад бодлогын хөгжил}

1993 оны 1 дүгээр сард Москва хотноо Монгол Улс ОХУ-тай “Монгол Улс, Оросын Холбооны Улсын найрсаг харилцаа, хамтын ажиллагааны тухай гэрээ”-г байгуулсан бөгөөд тус гэрээ нь манай хоёр орны харилцаа, хамтын ажиллагааг шинэ түвшинд гаргаж, өнөөгийн харилцааны эрх зүйн үндэс болсон байна. Тус гэрээний нэгдүгээр зүйлд Монгол Орос хоёр улсын цаашдын харилцаанд баримтлах зарчмуудыг тусгасан ба эдгээр зарчим нь хоёр тал бие биенийхээ тусгаар тогтнол болон бүрэн эрх, эрх тэгш байдал, нутаг дэвсгэрийн бүрэн бүтэн байдлыг хүндэтгэж, зэвсгээр айлган сүрдүүлэхгүй байх, хилийн дархан эрхийг үл хөндөх, дотоодын хэрэгт үл оролцох зэрэг маш чухал зарчмуудыг тусгасан нь Монгол, Орос хоёр улсын хоёр талын харилцаа цаашид хөгжин цэцэглэх үндэс болсон болно.

1991-2011 оны хооронд Монгол Улсын Ерөнхийлөгч 6 удаа, Ерөнхий сайд 9 удаа, УИХын дарга 5 удаа, Гадаад хэргийн сайд 5 удаа тус тус ОХУ-д айлчлал хийжээ. Мөн энэ хугацаанд ОХУ-ын Ерөнхийлөгч 2 удаа, Засгийн газрын тэргүүн 2 удаа, Холбооны Хурлын Холбооны Зөвлөлийн дарга 5 удаа, Төрийн Думын дарга 1 удаа, Гадаад хэргийн сайд 3 удаа Монгол Улсад айлчилсан байна.

Эдгээр хугацаанд хоёр орны төрийн тэргүүн нарын албан ёсны айлчлалын үеэр 2000 онд гарын үсэг зурсан “Улаанбаатарын Тунхаглал” нь хамтын ажиллагааны чиглэл, зорилтыг тодорхойлж Монгол Улс, ОХУ-ын харилцаа, хамтын ажиллагаа мэдэгдэхүйц идэвхжихэд чухал алхам болсон байна. Түүнчлэн 2006 онд гарын үсэг зурсан “Москвагийн тунхаглал”-д Монгол, Оросын харилцаа, хамтын ажиллагааг “стратегийн түншлэл” хэмээн тодорхойлсон нь чухал ач холбогдолтой болов.

1994 онд Монгол Улс, БНХАУ-ын хооронд 1960 онд байгуулсан “Найрамдал, харилцан туслалцах гэрээ”-г шинэчлэн байгуулахаар шийдвэрлэж Монгол, Хятад хоёр улсын ард түмний найрамдлыг бататган бэхжүүлэхийг эрмэлзэн “Найрсаг харилцаа, хамтын ажиллагааны тухай Гэрээ”-г соёрхон баталсан ба уг гэрээ нь хоёр орны цаашдын харилцаа эрvvл саруул, тогтвортой хөгжихэд улс төр, хууль зүйн үндэс суурь болсон байна. Тус гэрээний нэгдүгээр зүйлд “Хэлэлцэн тохирогч талууд бие биеийн тусгаар тогтнол, бүрэн эрхт байдал, нутаг дэвсгэрийн бүрэн бүтэн байдлыг харилцан хүндэтгэх, харилцан үл довтлох, дотоод хэрэгт үл оролцох, эрх тэгш, харилцан ашигтай байх, энх 
тайвнаар зэрэгцэн орших зарчмын үндсэн дээр хоёр улсын сайн хөршийн найрсаг харилцаа, хамтын ажиллагааг хөгжүүлнэ” хэмээн заасан байна.

1990 оноос хойш хоёр орны төрийн дээд түвшний айлчлал тасралтгүй үргэлжилж, сайн хөршийн харилцан итгэсэн түншлэлийн харилцааг улам хөгжүүлсээр байна.

\section{2 “Гуравдагч хөрш орон”-ы гадаад харилцааны бодлогын хөгжил}

Гуравдагч хөршийн бодлого гэдэг нь түүхийн турш Монголд нөлөөтэй байсан хоёр их гүрэн болох Орос, Хятадаас өөр бусад улстай харилцаа тогтоохдоо баримтлаж буй Монгол Улсын гадаад бодлогыг хэлнэ.

Энэхүү бодлого “Үндэсний аюулгүй байдлын үзэл баримтлал”, “Гадаад бодлогын үзэл баримтлал” зэрэг тулгуур баримт бичигт тусгалаа олсон байдаг. Тухайлбал, 2011 онд шинэчлэгдэн батлагдсан Монгол Улсын “Гадаад бодлогын үзэл баримтлал”-д “ОХУ, БНХАУ-тай найрсаг харилцаатай байх нь Монгол Улсын гадаад харилцааны бодлогын эн тэргүүний зорилт мөн” гээд гадаад бодлогын дараагийн үндсэн чиглэл болгон “АНУ, Япон, Европын холбоо, Энэтхэг, БНСУ, Турк зэрэг Өрнө, Дорнын улсуудтай холбоотой “гуравдагч хөрш”-ийн бодлогын хүрээнд түншлэлийн харилцаа, хамтын ажиллагааг өргөжүүлэн хөгжүүлэх"-ээр заасан байдаг.

\section{Гурав. Монгол Улсын “олон тулгуурт” гадаад харилцааны бодлогын хязгаарлах}

\section{элемент ба ирээдүйн чиг хандлага}

Хэдийгээр “олон тулгуурт” гадаад харилцааны бодлогыг хэрэгжүүлснээр Монгол Улсын олон улсын тавцан дах байр суурь сайжирсан боловч түүнд нөлөөлөх гадны нөлөө болон хязгаарлалт маш олон талтай байсаар байна.

\section{1 Монгол Улсын “олон тулгуурт” гадаад харилцааны бодлогын хязгаарлах элементүуд}

Монгол Улс нь хөрш 2 улстай шийдвэрлээгүй олон асуудал байгаа юм. Тухайлбал: БНХАУ-тай 2 улсын түҮхийн холбоотой асуудал байгаа бол ОХУ-тай эдийн засгийн өр ширийн асуудал оршсоор байна.

Түүнчлэн Монгол Улс болон “гуравдагч хөрш орон”-уудын хоорондын харилцаанд маш том тодорхой бус зүйлүүд ч бас байсаар байна. Ойрын жилүүдэд Монгол Улс нь Америк, Япон, Герман зэрэг улстай харилцаагаа маш идэвхтэйгээр хөгжүүлж байгаа бөгөөд ялангуяа Америктай цэргийн бэлтгэл ихээхэн хамтран хийдэг болсон. 1994 оноос одоог хүртэл АНУ Монголын батлан хамгаалахын сургууль, сургалт, бэлтгэл зэрэгт шууд туслалцаа өгснөөр барахгүй олон удаа хамтарч цэргийн хээрийн сургууль хийлээ. Америкийн энэхүҮ туслалцаа нь өөрийн улсын олон улсын стратегийн эрх ашгийг бодсоноос гадна, Монгол хэмээх энэхүү “тэнцвэржүүлэгч”-ийн газар зүйн ашигтай 
байдлаар Орос, Хятад 2 улсад нөлөөлөх явдал юм. Монгол Улс нь том гүрнүүдийн хоорондын хүчийг тэнцвэржүүлэх нэгэн гүүр болж байгаагаараа олон улсын тавцанд Монгол Улсын нөлөөллийг мөн нэмэгдүүлж байна.

\section{2 Монгол Улсын гадаад харилцааны бодлогын ирээдүйн чиг хандлага}

Өнөөгийн дэлхийн улс төрийн тавцанд Монгол Улс хараахан хүчирхэгжиж амжаагүй байгаa тул өөрийн орны эрх ашгийг хамгаалахын тулд “олон тулгуурт гадаад харилцааны бодлого”-ыг хэрэгжүүлж байна. Энэхүү бодлогын гол тулгуур цэг нь өөрийн улсын газар зүйн давуу талыг ашиглан улс эх орныхоо эрх ашиг, аюулгүй байдлыг хамгаалах явдал юм. Иймээс Монгол Улсын гадаад харилцааны бодлогын ирээдүйн чиг хандлага нь “олон тулгуурт гадаад харилцааны бодлого”-ыг үндэслэн улс төр, эдийн засаг, батлан хамгаалахын салбар гэх мэт бүх талаар олон улсад байр сууриа бэхжүүлэх явдал юм.

Монгол Улс газар зүйн байрлалаас хамаарч Орос, Хятадтай улс төрийн салбарт нэг хилийн шугам, нэг улс төрийн ашиг сонирхолтой учраас цаашид хөршүүдтэй харилцан итгэлцлээ улам баталгаажуулах хэрэгтэй байгаа болно. Монгол Улс нь дараах хоёр замаар хоёр хөрштэйгээ харилцан итгэлцлээ баталгаажуулж болно.Үүнд:

Нэг: Хөрш улсуудтай улс төрийн яриа хэлэлцээрийг эрчимжүүлж, дээд, өндөр хэмжээнд төлөөлөгчид харилцан айлчлах, ингэснээр харилцан ойлголцлыг нэмэгдүүлэх,

Хоёр: Хөршүүдтэй хоёр талын болон олон талын хамтын ажиллагааг сайжруулах, Монгол Улсын газар зүйн ашигтай байдлыг ашиглан хамтын ажиллагаагаар итгэлцлээ баталгаажуулах зэрэг болно.

Батлан хамгаалахын салбарт Монгол Улс нь “эвсэлд үл нэгдэх” бодлогыг баримтлах хэрэгтэй бөгөөд Монгол Улсын газар зүйн онцлог байдлаас шалтгаалан дэлхийн том том улсууд өөр өөрсдийн эрх ашгийн үүднээс Монгол Улстай харилцаагаа өдөр ирэх тусам өргөжүүлж ирсээр байна. Ялангуяа батлан хамгаалахын салбарт илүү ихээр хамтран ажилласаар байна. Иймээс одоогийн ийм ээдрээтэй олон улсын улс төрийн орчинд дасан зохицохын тулд Монгол Улс маш сэргэг байж “эвсэлд үл нэгдэх” гадаад харилцааны бодлогоо улам сайн баримтлах хэрэгтэй юм. Ингэж байж л том гүрнүүдтэй нарийн ширийн асуудалд өөрийн зүгээс асуудлыг зөв шийдэх болно. Тиймээс “эвсэлд үл нийцэх" гадаад харилцааны бодлогыг хатуу чанга баримтлахын сацуу юуны өмнө Орос, Хятад улстай ижил тэнцүү, нөхөрсөг хамтын ажиллагааг хөгжүүлэх хэрэгтэй болохыг улс төрийн өнөөгийн байдал харуулж байна. 


\section{ДҮГНЭЛТ}

Монгол Улсын одоо хэрэгжүүлж буй “олон тулгуурт” гадаад харилцааны бодлого нь хүйтэн дайны үед баримталж байсан “нэг тал”-ыг баримталсан гадаад харилцааны бодлогоос илүү чухал хэрэгцээтэй байгаа болно. Энэхүү бодлого нь Монгол Улсыг зөвхөн нэг улс руу чиглэсэн хаалттай бодлогоос чөлөөлөн мөн дотоодын улс төр, эдийн засаг болон батлан хамгаалахын салбар эрчимтэй хөгжихөд ихээхэн үүрэг гүйцэтгэж байгаа тул одоогийн олон улсын ээдрээтэй улс төрийн орчинд дахин нэлээд удаан хугацаанд үргэлжлүүлэн “олон тулгуурт” гадаад харилцааны бодлогыг баримталж явах нь зүйтэй хэрэг болно. 